\title{
Intermediate Care Facility
}

National Cancer Institute

\section{Source}

National Cancer Institute. Intermediate Care Facility. NCI Thesaurus. Code C99912.

A medical center that provides care 24 hours per day. (ACC) 